\title{
A Phenomenal Conservatist Response to Covenantal Epistemology
}

\section{Logan Paul Gage and Blake McAllister}

Oliphint's version of Covenantal Epistemology includes theses in both of the following areas:

I. The general relationship between epistemological theorizing and Christian revelation (particularly as embodied in scripture).

II. Specific epistemic principles gleaned from Christian revelation.

First, we will challenge Oliphint's reading of scripture. This is not a critique of the Covenantal approach per se but rather Oliphint's particular outworking of it. Afterward, we will challenge Oliphint's understanding of the general relationship between scripture and epistemology.

\section{\$1 What Does Scripture Teach Us about Knowledge of God?}

There is a conceptual distinction between what scripture says and what Oliphint interprets scripture as saying. No doubt Oliphint is striving to make his interpretation match that which is revealed through scripture, but God does not guarantee that our personal attempts to interpret scripture be infallible and free from error, as Oliphint surely agrees. It follows that to critique Oliphint's view is not to critique scripture, but only his interpretation of it. 
As far as we can tell, Oliphint maintains that all of the following can be gleaned from a proper reading of the Bible:

II.a. God, if he is to be known by us at all, must make Himself known through a special act of revelation. (By a "special act" we mean one that goes beyond God's mere creation of humans and the bestowal upon them of standard rational faculties capable of gathering knowledge.)

II.b. All our knowledge of God is implanted in us by God through a special act.

II.c. We are wholly passive in the reception of this knowledge. Our rational faculties play no role in the acquisition of this knowledge or any part of it.

II.d. Our knowledge of God is not an ordinary kind of knowledge involving justified belief in a proposition, but is a special, personal kind of knowledge. ${ }^{1}$

Oliphint offers several lines of support for these theses, none of which have us convinced.

First, Oliphint appeals to God's incomprehensibility to us creatures. Oliphint seems to think that God's incomprehensibility provides support for II.a. We disagree. Notice that the traditional doctrine of God's incomprehensibility does not maintain that we creatures can know nothing about God, but only that we cannot know everything about God. There is a full and complete comprehension of God that is beyond our grasp (even after we have received the beatific vision, in fact). Regarding those aspects of God that can be known to us, however, the doctrine says nothing about which methods God must use to reveal these things.

The doctrine of incomprehensibility aside, it is generally accepted that there are some aspects of God which can, in principle, be known by us that cannot be accessed through our God-given rational faculties alone. But again, it does not follow that everything knowable about God is inaccessible to our rational faculties. Why can't it be that some aspects of God can be known by us through our God-given rational faculties and others must be made known through a special act of revelation? Consider the traditional distinction, exampled by Aquinas, between general revelation and special revelation. ${ }^{2}$ Aquinas maintains that God's existence and basic attributes are accessible to humans through reason alone, but that such knowledge is insufficient for knowledge of some important divine attributes, such as God being triune, let alone for salvation. Thus, God acts in a special way to reveal that which 
is lacking. Such an alternative position acknowledges that much of God is inaccessible to our unaided rational powers (especially after the Fall) while avoiding the extreme position that we are unable to know anything at all about God apart from His special intervention. It is surprising that Oliphint does not consider such a position, especially given its prominence in the Christian tradition. Regardless, the crucial point is that this alternative has as good a claim to being the scriptural view as II.a., if not better.

Oliphint's second line of support comes from Rom. 1, especially v. 19: "For what can be known about God is plain to them, because God has shown it to them." This verse states that God provides knowledge of Himself to humans. But what are the specific means by which God reveals Himself to humanity? Remarkably, Oliphint thinks that II.b. and II.c. are both established by this verse. That is, he concludes from the phrase "because God has shown it to them" that our knowledge of God is implanted in us by a special act of revelation and that our rational faculties play no active role whatsoever in the reception of this knowledge. We think it clear that informed and faithful readers of scripture can disagree with Oliphint's specific interpretation of this verse. For instance, why can't God show Himself to humans simply by creating them with rational faculties capable of readily grasping His existence? Indeed, that view fits better with the next verse, which states, "For his invisible attributes, namely, his eternal power and divine nature, have been clearly perceived, ever since the creation of the world, in the things that have been made." On Oliphint's view, in what way are God's attributes perceived "in the things that have been made?" Our knowledge is directly implanted by God; the perception of nature plays no substantive role in it. Whereas on the alternative we're proposing, reason acting on observations of nature can lead us to knowledge of God. Our point is not to defend this alternative interpretation as much as to show that there are plausible alternatives to Oliphint's reading. Thus, he has failed to established II.b. and II.c. as the position of scripture.

The same critique can be lodged against Oliphint's defense of II.d., which he also claims to find in Rom. 1. Putting aside the fact that Oliphint gives us little idea what this personal kind of knowledge is supposed to be, where exactly does he find this specific sort of knowledge being talked about by Paul? Oliphint doesn't tell us. No doubt Oliphint could say more were he given the opportunity to further defend his interpretation, but looking only at what he does say, he has not shown that II.d. is implied by Rom. 1 or any other part of scripture. 


\section{§2 Epistemology and Scripture}

It is not entirely clear to us what exactly the Covenantal approach maintains about the relationship between epistemology and scripture. At times, some of what Oliphint says sounds like he's endorsing the following:

I.a. In our fallen state, we are only capable of discerning epistemological truths with the aid of scripture.

We think this view is mistaken. (If this is not Oliphint's view, then consider this an opportunity for Oliphint to clarify his position.)

Let us begin by affirming that scripture can give us insight into epistemology. We would contest only that epistemological insight is exclusively gained through the aid of scripture. As a comparison, it is sensible to think that scripture can teach us something about history, psychology, medicine, science, or even mathematics; but it is false to think that our only access to these areas is through scripture. We do not tell the archeologist to stop digging or the scientist to stop experimenting. This is because God gave us rational faculties capable of gaining insight into such areas apart from special revelation. Note, the claim here is not that we can fully understand creation without understanding God's role in it. We are making the more moderate claim that God gave us rational faculties capable of grasping some truths about the world without requiring an intricate system of theology to be operating in the background. If this is true in all the aforementioned disciplines, why would we expect matters to be different in epistemology? Sin affects our minds, to be sure. But the effects of sin do not prevent the mathematician from obtaining at least some mathematical truth. The matter is no different for epistemologists. Our cognitive faculties are damaged, but this does not render them entirely useless. $^{3}$

It is good that this is so, for while scripture can provide some insight into epistemology, it doesn't address every important question we have. The same is true in any of the aforementioned disciplines. Scripture gives us great insight into history, but there's lots about history that scripture doesn't tell us. In the same way, there is much we would like to know in epistemology that scripture does not address, or does not address in sufficient detail. It would seem that the Covenantal approach has little to say about such issues. If we want answers, we must be willing to use other resources in addition to scripture-in particular, our God-given rational faculties. 
When we acknowledge that non-scriptural resources are available to us and are capable of leading us to truth, it becomes implausible to maintain that we cannot do epistemology without our conclusions being firmly rooted in scripture or right relationship with God. That's not true in history or science or mathematics, and it's not true in epistemology.

\section{Notes}

1. At least, we think this is what Oliphint maintains. It's not altogether clear.

2. See, for instance, the first question of the Summa Theologica where Aquinas argues, "It was therefore necessary that besides philosophical science built up by reason, there should be a sacred science learned through revelation."

3. This has been the view of many great Christian theologians. In his Confessions (V.III), for example, Augustine holds that while the secular astronomers/ astrologers of his day use their God-given faculties to discover many true things about the universe, this learning doesn't reach its true telos. That is, while they have genuine knowledge, these secular scientists do not offer up their lives and work as worship and sacrifice to God. Citing Romans 1, Augustine holds that their learning doesn't go far enough, doesn't reflect back up on the author of nature. Secular learning can be genuine learningwithout being grounded in scripture and even without a right relationship with God. But, Augustine emphasizes, it is spiritually (and ultimately) fruitless if it leads to pride rather than humility before God. 